\title{
Address by the President of the Institute and Faculty of Actuaries Dr John Taylor
}

\author{
John Taylor \\ [Delivered to the Institute and Faculty of Actuaries, Edinburgh, 26 June 2019] \\ Contact: presidents@actuaries.org.uk
}

The President (Dr J. Taylor, F.F.A.): Good evening from Edinburgh. Today marks the first-ever presidential address of the merged Institute and Faculty of Actuaries (IFoA) to take place outside of London.

You do not get to deliver many presidential addresses in your career. And, until very recently, I had not anticipated delivering a single one. Over the last few months, I have been looking back at previous presidential addresses as well as some of the great speeches by public figures. I rediscovered a wonderful Scottish speech and I would like to quote from it. It is still remembered by some, and at the time, it was a sensation. The New York Times called it the greatest speech since Lincoln's Gettysburg Address. It was delivered by a former shipbuilder Jimmy Reid, who went on to become rector of Glasgow University in 1972. It is a wonderful speech for many reasons, as he talks about the human condition in the modern world. He even explores concerns then that automation would make humans redundant. I would encourage you to look at it online. I would like to quote this passage:

"I am convinced that the great mass of our people go through life without even a glimmer of what they could have contributed to their fellow human beings. This is a personal tragedy. It's a social crime.

The flowering of each individual's personality and talents is the pre-condition for everyone's development."

It is a profound thought, on a human level. I contend this evening, in Edinburgh and 50 years later, that it also has profound significance for the work that we do as actuaries - that our talents have not yet fully blossomed, that we can contribute more to our fellow human beings.

As a proud member of the Scottish Constituency, I am thrilled to bring the AGM here as a way of honouring Scotland's own contribution to the profession. You can probably trace the Scottish roots back at least 300 years. Around then, and not far from this building, David Hume and then Reverend Thomas Bayes were laying the foundations of probability theory. A century after that, their work was influential in the creation of the world's first funded pension scheme, for the widows of Scottish ministers.

Despite this local success, England actually pipped Scotland to establish the world's first professional body for actuaries. The Institute of Actuaries was formed in London in 1848, 8 years before Scotland had its Faculty. The Scots in the audience tonight might take some quiet satisfaction in being reminded that the very first president of the London-based Institute was the renowned Scottish actuary, John Finlaison. The Scottish influence has continued ever since. 
With echoes of Finlaison, the very first president of the merged IFoA was another renowned Scottish actuary, Ronnie Bowie.

Now it is time for me to wear the President's medallion. But I do not think of it as a medallion. It is more of a relay baton - hopefully not the sort of relay where we all go around in circles! More like the Olympic torch, and, like that torch, this one has travelled a long way. It has been through many hands since John Finlaison first carried it. It has got Ronnie (Bowie)'s fingerprints on it. It has got Marjorie Ngwenya's too. Jules Constantinou carried it admirably last year and so I now take the flame burning brightly. It is my turn to produce a year's "worth of distance run". And then to hand it over securely to Tan Suee Chieh. I thank Council for choosing me to run this leg.

Like many of these endurance events, it is not just about the athlete. There is often a big support team. Those closest to me, my wife Sylvie and daughter Alice, are on my team. The IFoA executive team, led by Derek Cribb for the last 10 years, has supported many presidents. Moreover, the wider team of 4,000 actuary volunteers, who work in partnership with the staff, has helped the IFoA punch well above its weight. My thanks go to all of you, both past and present.

My personal race started 50 years ago in the West of Scotland. Like many of you, I discovered a work ethic and a love of numbers early on. A careers adviser told me that the actuarial profession would let me indulge that passion for maths and be well paid for it. That same background led my only sibling, Kenneth, into the actuarial profession too. So, my mother and father can be proud of the contribution they have made to the actuarial profession, even though they have something to learn about concentration of risk!

I went on to complete a BSc and then a PhD in Mathematics at Glasgow University. A further year's study at Heriot-Watt University, Edinburgh, saw me attaining the diploma in Actuarial Mathematics. At that time, there were no university fees to be paid and, thanks to government funding and no small amount of parental funding, I could do so without racking up the debt that some of the younger actuaries in this room may have. So I hope that, in some way, the work I do as President to prepare the profession for future generations is me "giving back".

After all that free formal education, I could not avoid work any longer. For the first few years at Standard Life in Edinburgh, I performed traditional actuarial work. Being an actuary that looked at "the other person's shoes", I enjoyed the dynamism of sales and quickly secured a transfer to the sales team in London. I have led sales and marketing functions for a variety of product providers ever since, never returning to traditional actuarial work.

As I moved up the career ladder, I experienced something of a gradual revelation. I would spend more time finding out about what mattered to customers, through quantitative research, eavesdropping on customer phone calls and being a voyeur at focus groups. There are, of course, financial conversations with friends, family and neighbours. I had a much better sense of the good we can do when we get it right, and the harm when we get it wrong. So, I really started to feel a keen sense of responsibility towards those who relied on us.

That led to volunteering for an IFoA working party, aiming at improving people's retirements. It did not take long before I stood for Council and a few years later, I was being encouraged to put myself forward as a Presidential candidate. After surviving the last year on probation as Presidentelect, I now have another privilege, that of sharing my priorities with you.

I am going to start with the IFoA itself and how it connects with you, the members.

There was a time when the profession was much smaller than it is today, like a club. Members knew one another and members even ran the profession itself. Many decades of growth have demanded that the IFoA transform into an efficient machine. Each year, it whirs away to support almost 32,000 members, deliver over 38,000 exams at over 140 global exam centres and distributes more than 350,000 copies of The Actuary magazine. The transformation from small club to a productive machine has been necessary and impressive.

But as I speak to fellow members, I often hear the same complaint - that big machine is so noisy now that it cannot hear us any longer, that our voice does not matter. This has to change. I want 
the IFoA to listen more. I want the IFoA to be more attuned to your needs, whether you are a student, an Associate or a Fellow, and whatever your gender, ethnicity or nationality.

So, we made a concerted effort to listen to you through the survey we issued late last year. You told us about fee levels. The Fellowship subscription rate has actually lagged inflation by $19 \%$ over the last decade. But you told us that it was still too high! And we heard you! We will be reducing Fellowship and Student subscriptions for the first time ever in the coming year. Economies of scale have allowed us to make this small but significant step.

You also told us the IFoA is not always easy to deal with. The current joining process can take up to 7 weeks after the form is downloaded, filled in and posted off to us.

On the other hand, I joined a challenger bank online recently. Five minutes on an app to scan ID and it was done. So, we are investing in processes to make them better.

Processes and fees are only part of the story. A key part of being an actuary is belonging to a community, whether that is your practice, your geography or both. Indeed, the Scottish community today remains a wonderful example of a vibrant and active community. I hope the IFoA can help other countries and regions develop their similar communities.

Yes, we need this efficient machine as the foundation in order to serve you well. But I want you to be heard, both by the IFoA and in your communities.

Let me tell you about my priorities outside of the professional body.

The pace of technological change is phenomenal. We look at it in our daily lives with a mixture of wonder and awe.

Some predict the demise of all professions, including actuaries - that there might be a presidential bot delivering this address in years to come. But I believe technology is not our foe, it is our friend. We now have the best toolbox that any actuary has ever had, one that John Finlaison could barely imagine. Using that toolbox will help us create and shape new opportunities to deploy our hard-earned actuarial expertise.

The essence of the profession has been forged in the traditional domains of insurance and pensions. We have developed excellence in applying maths and statistics in business. We do so steeped in professional integrity, mindful of the public interest. Technology will help us to innovate and remain leaders in those traditional domains for decades to come.

There is an even bigger opportunity outside those domains. Every industry sector is being fundamentally altered by the deluge of data. Institutions are struggling to create value from it. That is the essence of our opportunity. It is an opportunity that some actuaries are already realising.

In Australia, for example, actuaries are heavily involved in data science, even helping supermarkets use data to choose which products to stock. Actuaries are also using data to become more involved in environmental issues through the creation of Climate Change Indices.

We are even involved in one of the most creative and artistic sectors - advertising. It is said of that field that the "Mad Men" of TV series fame are now being replaced by "Math Men". There are, of course, "Math Women" too.

That is what the pioneers are doing. The profession can realise the broader opportunity only if we keep our skills current. Indeed, we have a professional obligation to ensure our skills remain current, and to engage in continual lifelong learning. Whilst the onus is on each of us to learn and to develop ourselves, you have consistently given us feedback that you would value more support on data science.

We have been acutely aware of the enthusiasm amongst qualified actuaries for formal data science education, from both you as individuals and from your employers. We recognise that many companies are undertaking lifelong learning in this area and I am delighted to announce tonight the launch of the IFoA's online Certificate in Data Science.

This credential will be available to our members at all stages of their careers and wherever they are located across the globe. It will cover topics such as Data Visualisation, Machine Learning, AI and Ethics, and the application of these to actuarial work. It will help you understand the art of the possible with that amazing toolbox. 
We expect enrolment to start in March next year. More details will be on our website from tomorrow. You will also find great IFoA and third-party content on data science, including sessions from our virtual data science conference in which 3,000 members participated. So, by retaining our essential skills and opening that toolbox, we can embark on a golden age for the profession.

I want now to turn to the second external consideration and, indeed, our raison d'etre - serving the public interest.

Only a minority of people know what an actuary is and very few have ever read an actuarial report. Without knowing it, hundreds of millions worldwide rely on actuaries to give them confidence that their savings and pensions are secure, to know that they can depend on insurance.

Ordinary savers may never know much about actuaries, but we can learn more about them. Even we actuaries sometimes take that for granted, so I would encourage you to take opportunities to find out more about ordinary savers. If you are working on an insurer's balance sheet, take a trip to the call centre. If you are valuing a pension fund, go to an employee seminar.

Even from our own end of the telescope, we know that a profound shift is taking place for ordinary people. We know institutions that once shouldered risks on behalf of individuals are no longer willing to do so. Employers have been turning their backs on investment and longevity risks for many years by closing final salary schemes. Insurance companies are less willing to set aside capital to support the long-term investment and longevity guarantees.

It is clear to us that employers and insurance companies have been successful in reducing their exposures. The underlying risks have not gone away. They now rest with individuals.

And so ordinary people, who were once protected from investment volatility thanks to withprofits and defined benefit schemes, no longer have that protection. Pensioners who once had a guaranteed income for life now worry about running out of money. What kind of progress is this?

With more than a hint of Orwellian doublespeak, this is sometimes referred to as "the democratisation of risk". I am not sure many individuals welcome the fact that these actuarial risks have been passed on to them. Individuals may not even realise the responsibility is theirs, let alone have the aptitude to deal with it.

If serving the public interest means anything, it means we have an obligation to help. We are the masters at managing actuarial risks. We need to find ways of helping individuals. And there are reasons to be optimistic.

We are seeing the emergence of new forms of pensions, such as Collective Defined Contribution, in Europe and now in the UK, that protect individuals from these risks.

And, at an early stage of development, the IFoA's Actuarial Research Centre is sponsoring research that could provide retirees with longevity protection within drawdown.

For individuals managing their own finances, "robo-advice" is using data analytics to deliver personalised assessments and recommendations to individuals, helping them to better manage the risks they face.

Robo-advice is a great illustration of technology being our friend in this endeavour, serving consumers. In Africa earlier this month, I saw another use of technology to help consumers. Mobile phone networks are being used to offer insurance to poorer populations for as little as $\$ 2$ per month.

It is great to see actuaries involved in these initiatives. At the IFoA, we are helping policymakers deal with these issues. The Certificate in Data Science is another enabler, but there is more to do. Please email me at presidents@actuaries.org.uk if you have suggestions for the profession in this area.

Whether you see it from the perspective of serving the public interest or you simply see the commercial opportunity, the conclusion is the same. Helping individuals manage those risks will be vital, not only to their future but also for our own. To borrow again from Jimmy Reid, let us make sure our talents flower so that we can better help our fellow human beings.

Cite this article: Taylor J. Address by the President of the Institute and Faculty of Actuaries Dr John Taylor. British Actuarial Journal. https://doi.org/10.1017/S1357321720000240 